\title{
UJI EFEKTIVITAS EKSTRAK BUAH PARE (Momordica charantia) PADA MORTALITAS LARVA Aedes aegypti
}

\author{
Gandung Prakoso ${ }^{\star}$ Agus Aulung ${ }^{\star \star}$ dan Mila Citrawati*** \\ *Program Studi Sarjana Kedokteran, Fakultas Kedokteran UPN “Veteran” Jakarta \\ ${ }^{* *}$ Departemen Parasitologi,Fakultas Kedokteran Universitas Indonesia \\ *** Departemen Parasitologi,Fakultas Kedokteran UPN “Veteran” Jakarta \\ Jl. RS Fatmawati, Pondok Labu, Jakarta Selatan 12450, Telp. (021) 7656971 \\ Homepage: http://www.jurnal.fk.upnvj.ac.id
}

\begin{abstract}
Abstrak
demam berdarah dengue (DBD) merupakan masalah utama kesehatan masyarakat di seluruh dunia. Biolarvisida adalah strategi untuk menekan kejadian DBD. Buah pare mengandung konstituen biokimia seperti alkaloid, saponin, flavonoid, steroid, dan momordicine yang memiliki efek larvasida. Penelitian ini bertujuan untuk mengetahui efektifitas ekstrak buah pare sebagai larvasida dari aedes aegypti larva. Desain penelitian ini adalah eksperimental. Sampel dari penelitian ini adalah ekstrak buah pare. Ekstrak buah pare dibagi menjadi 4 konsentrasi digunakan yaitu, 0,8\%, 1,6\%, 3,2\%, 6,4\%, dan kontrol negatif. Penelitian ini menggunakan metode bioassay dengan 20 instar III dan IV larva nyamuk aedes aegypti dimasukkan ke dalam wadah dan diinkubasi selama 24 jam. Menurut hasil uji Kruskall-Wallis $(\mathrm{p}=0,005)$ ada perbedaan yang signifikan ekstrak buah pare terhadap kematian larva aedes aegypti. Hasil uji Mann-Whitney menunjukkan bahwa terdapat perbedaan signifikan efektifitas konsentrasi ekstrak buah pare yang dibandingkan dengan kontrol. Hasil analisis probit menunjukkan bahwa LC50 dan LC90 nilai yang 1.207\% dan 2.759\%, masing-masing. Menurut penelitian ini, ekstrak buah pare memiliki efek larvasida aedes aegypti.
\end{abstract}

Kata kunci: Bitter melon ekstrak buah, larva Aedes aegyptyi, larvasida

\section{Abstract}

Dengue hemorrhagic fever (DHF) is a major worldwide public health problem. Biolarvicide is a strategy to suppress the incidence of DHF. Bitter melon fruit contains biochemical constituents such as alkaloid, saponin, flavonoid, steroid, and momordicine which have larvicidal effect. This study was aimed to know the effectivity of bitter melon fruit extract as a larvicide of Aedesaegypti larva. The design of this study was experimental. The sample of this study was bitter melon fruit extract. There were 4 concentrationsof bitter melon extract used i.e., 0,8\%, 1,6\%,3,2\%, 6,4\%, and negative control. This study used bioassay method with 20 instar III and IV larvas of Aedesaegypti put into container and were incubated for 24 hours. According to result of Kruskall-Wallis test $(p=0,005)$ there was a significant difference effectof bitter melon extractonthe mortality of Aedesaegypti larva. The result of Mann-Whitney test showed that there was asignificant difference in the effectivity among the concentrationsof bitter melon extract being compared and control solution. The result of probit analysis showed that LC50 and LC90 values were 1,207\% and 2,759\%, respectively. According to this study, bitter melon fruit extract has larvicide effectonthe mortality of Aedesaegypti.

Keywords: Bitter melon fruit extract, Aedesaegyptyilarva, larvicide 


\section{PENDAHULUAN}

Demam berdarah dengue (DBD) merupakan masalah publik kesehatan di dunia. DBD adalah suatu penyakit infeksi yang disebabkan oleh infeksi virus dengue danditularkan oleh vektor berupa nyamuk, yaituAedes aegypti(Natadisastra \& Agoes, 2009; Sapir \& Schimmer 2005).Permasalahan DBD sudah meningkat empat kali sejak tiga dekade terakhir. Saat ini terdapat 2,5 miliar orang berisiko untuk terkena penyakit DBD (WHO, 2011).Lebih dari 100 negara di daerahtropis dan subtropis pernah mengalami kejadian luar biasa (KLB) kasus DBDdengan lebih kurang 500.000 kasus setiap tahun dirawat di rumah sakit dengan ribuan orang di antaranya meninggal dunia (Majidah et al, 2010).Untuk Indonesia sendiri, berdasarkan data pada tahun 2009 tampakbahwa penduduk Indonesia yang terinfeksi virus dengue berjumlah 156.052. Jumlah ini meningkat sekitar 1000 dari tahun sebelumnya. Selain itu, jumlah pasien yang meninggal akibat DBD pada tahun 2009 berjumlah 1396. Jumlah ini naik 400 orang dari tahun 2008 (WHO, 2011).

Upaya penanggulangan penyakit demam dengue (DD) dan DBD dapat dilakukan dengan memutus salah satu rantai segitiga epidemiologi (Triangle of Epidemiology), yaitu melalui pengendalian vektor. Pengendalian vektorAedes aegypti dapat dilakukan dengan menggunakan insektisida (Nisa et al, 2012). Terdapat dua jenis insektisida, yaitu insektisida sintetis dan insektisida nabati (Ludvik, 2007). Penelitian Bisset et al(2011) menyatakan bahwa penggunaan temephos sebagai insektisida sintetis secara berkala akan menurunkan efektivitasnyapada nyamuk Aedes aegypti. Berdasarkan hasil penelitian Saryono et al(2012) kematian Aedes aegypti setelah diberikan insektisida sintetis memiliki nilai 0,8$13,6 \%$ yang menurut World Health Organization (WHO) termasuk klasifikasi resisten. Selain itu, penggunaan insektisida sintetis secara berlebihan dan dalam waktu yang panjang dapat menimbulkan kerugian,seperti nyamuk menjadi resisten, terjadinya keracu $\neg$ nan pada manusia dan hewan ternak, serta polusi lingkungan. Dengandemikian, perlu suatu usaha un $\neg$ tuk mendapatkan alternatif yang lebih efektif dalam mengendalikan populasi serangga. Salah satu alternatif pengendalian vektor adalah dengan penggunaan insektisida alami untuk mengurangi masalah pencemaran lingkungan (Hafriani, 2012). Fakta yang lebih penting adalah ekstrak tanaman terkadang lebih efektif dibanding insektisida sintetis karena mengandungmetabolit sekunder yang memiliki peran besar dalam mengkontrol nyamuk (Remia \& Logaswamy 2010).

Indonesia memiliki berbagai macam tanaman obat herbal(Depkes RI, 2007). Salah satunya adalah tanaman pare. Tanaman pare (Momordica charantia) merupakan salah satu tanaman herbal. Pare merupakan tanaman yang cukup dikenal di Indonesia dan sering diolah menjadi masakan. Buah pare mudah sekali ditemukan dan didapatkan di Indonesia. Buah pare telah dipercaya dan digunakan secara turun temurun sebagai obat tradisional (Nusmara, 2012; Budrat \& Shotipruk, 2008; Cahyadi, 2009). Buah pare mengandung beberapa senyawa aktif, yaitu glikosida, triterpenoid, flavonoid, karantin, resin, steroid, saponin, dan alkaloid yang berfungsi sebagai antimikrob dan insektisida (Hasna et al, 2013; Gupta et al, 2011). Flavonoid dapat masuk melalui kutikula yang melapisi tubuh larva sehingga dapat merusak membran sel larva serta bekerja sebagai inhibitor kuat sistem pernapasan atau sebagai racun pernapasan (Cania \& Setyaningrum, 2013). Saponin bekerja dengan mengiritasi mukosa saluran pencernaan serta memiliki rasa pahit sehingga dapat menurunkan nafsu makanlarva sehingga efek yang timbul adalah kematian larva. Selain itu, saponin merusak lapisan lilin yang melindungi tubuh serangga bagian luar sehingga kehilangan banyak cairan tubuh dan mengakibatkan kematian (Minarni et al, 2013). Alkaloid dapat mengganggu kerja saraf larva dengan menghambat enzim asetilkolinesterase sehingga terjadi penumpukan asetilkolin (Cania \& Setyaningrum, 2013). Buah pare juga mengandung senyawa momordisin I, II, momorkarin, dan momordin yang merupakan protein sitotoksik sehingga akan merusak ribosom larva (Britto \& Gracelin, 2011).

Berdasarkan latar belakang yang telah digambarkan maka dapat dirumuskan masalah 
dalam penelitian ini adalah "apakah ekstrak buah pare memiliki efektivitas larvasida pada larva Aedes aegypti?" selanjutnya "berapakah nilai Lethal concentration 50 (LC50) dan Lethal concentration 90 (LC90)?

\section{METODE PENELITIAN}

Jenis penelitian ini adalah eksperimental. Pada penelitian ini, peneliti melakukan manipulasi satu atau lebih variabel penelitian dan kemudian mempelajari efek perlakuan tersebut. Metode penelitian yang digunakan adalah eksperimen semu. Penelitian ini dilakukan di Laboratorium Parasitologi, Fakultas Kedokteran, Universitas Pembangunan Nasional "Veteran" Jakarta pada bulan Mei 2015. Sampel penelitian ini adalah ekstrak buah pare yang berasal dari Balai Penelitian Tanaman Obat dan Aromatik (BALITTRO) Kota Bogor, Jawa Barat. Subjek penelitian yang digunakan adalah larva Aedes aegypti instar III dan IV. Berdasarkan rumus Federer didapatkan pengulangan lima kali.

Proses Ekstraksi

Buah pare kering yang telah menjadi serbuk dengan grinder dilarutkan dengan pelarut etanol $70 \%$ dan diaduk dengan stirer selama +3 jam kemudian diendapkan selama 24 jam. Endapan akan membentuk filtrat I dan ampas. Ampas ditambah pelarut kembali dan diaduk dengan stirer selama +1 jam kemudian disaring dengan kertas saring menghasilkan filtrat II. Filtrat I dan filtrat II disatukan kemudian dirotavapor sampai kentaldandiuapkan pelarutnya pada suhu $50^{\circ} \mathrm{C}-60^{\circ} \mathrm{C}$ sehingga terbentuk ekstrak buah pare.

Pembiakan Hewan Uji

Urutan pembiakan Aedes aegypti dari telur hingga dewasa adalahsebagai berikut;

1) Kertas saring yang berisi telur Aedes aegypti ditempatkan di nampan berisi air agar menetas.

2) Setelah 1-3 hari terbentuk larva maka larva tersebut dipindahkan ke nampan lain yang sudah terisi air.

3) Setelah 6-7 hari akan terbentuk pupa. Pupa dipindahkan dengan pipet tetes ke gelas plastik ukuran $250 \mathrm{~mL}$ yang berisi air sampai $3 / 4$ bagian.
4) Gelas plastik yang telah berisi pupa dimasukkan kedalam kandang nyamuk.

5) Di salah satu sudut di dalam kandang nyamuk, dimasukkan $\pm 100 \mathrm{~mL}$ larutan sukrosa $10 \%$ untuk nyamuk jantan, sedangkan nyamuk betina diberi pakan darah yang berasal dari darah hewan.

6) Selain air gula, didalam kandang nyamuk juga disediakan tempat peletakan telur berupa gelas plastik bervolume 250 mLyang diisi air $3 / 4$ bagian dengan kertas saring yang ditempatkan mengelilingi permukaan air. Setelah telur yang melekat pada kertas saring jumlahnya cukup banyak maka kertas saring diambil bersama-sama dengan telur yang melekat di atasnya.

\section{Prosedur Penelitian}

Pada penelitian ini disiapkan 5 kontainer dengan larutan total yang sudahditentukansebanyak $100 \mathrm{~mL}$. Setiap kontainer diisi dengan variasi konsentrasi ekstrak buah pare, yaitu konsentrasi $0,8 \%, 1,6 \%, 3,2 \%$, dan $6,4 \%$ dengan menambahkan aquades sampai volume 100 $\mathrm{mL}$ serta 1 kontrol negatif, yaitu aquades tanpa pemberian ekstrak buah pare. Setelah itu dimasukkan 20 ekor larva Aedes aegypti instar III dan IV pada setiap kontainer lalu diinkubasi atau didiamkan selama 24 jam. Setelah 24 jam, dihitung jumlah larvaAedes aegyptiinstar III dan IV yang mati.

Analisis Data

Data dianalisis dengan menggunakan uji Kruskal-Walliskarena data yang didapatkantidak berdistribusi secaranormal. Jika dua syarat terpenuhi, yaitu data berdistribusi normal dan homogen maka dilakukan uji One-Way Annova. Setelah dilakukan uji KruskalWallis,hasilnyamenunjukkan bahwaterdapat perbedaan $(\mathrm{p}<0,05)$. Kemudian dilanjutkan dengananalisisPost Hoc dengan uji Mann-Whitneyantara setiap konsentrasi danantarasetiap konsentrasi dengan kontrol negatif.Jika didapatkan nilai $(\mathrm{p}<0,05)$ maka dikatakan terdapat perbedaan bermakna. Untuk mengetahui nilai LC50 dan LC90 maka dilakukan analisis probit 
HASIL DAN PEMBAHASAN

Tabel 1 Hasil Uji Fitokimia Ekstrak Buah Pare

\begin{tabular}{cc}
\hline Senyawa & Hasil \\
\hline Flavonoid & + \\
Sąonin & + \\
Alkaloid & + \\
Steroid & + \\
Triterpenoid & - \\
Polifenol & + \\
\hline
\end{tabular}

Setelah dilakukan uji fitokimia ternyata buah pare mengandung metabolit sekunder flavonoid, saponin, alkaloid, steroid, dan polifenol

Efek Larvasida Ekstrak Buah Pare

Setelah dilakukan inkubasi selama 24 jam maka dilakukan perhitungan jumlah larva yang mati.

Tabel 2 Rerata Kematian Larva Aedes aegypti Setelah Terpajan Ekstrak Buah Pare Selama 24 jam

\begin{tabular}{lc}
\hline Kelompok & Rerata Kematian \\
\hline $0,8 \%$ & 8,6 \\
$1,6 \%$ & 14 \\
$3,2 \%$ & 18,4 \\
$6,4 \%$ & 20 \\
Kontrol Negatif & 0 \\
\hline
\end{tabular}

Berdasarkan Tabel 2 didapatkan bahwa ekstrak buah pare memiliki efek larvasida pada larva Aedes aegypti. Kematian larva Aedes aegypti dimulai padakonsentrasi $0,8 \%$ dan semakin tinggi konsentrasi ekstrak buah pare, daya larvasida pun semakin besar. Kematiansemualarva Aedes aegyptiditemukanpadakonsentrasiekstrakbuah pare 6,4\%. Pada konsentrasi $0 \%$ ataukontrol tidak ditemukan kematian larva Aedes aegypti. Hal ini membuktikan bahwa kematian larva Aedes aegypti disebabkan oleh pengaruhekstrak buah pare, bukan disebabkan oleh variabel pengganggulain.
Tabel 3 Hasil Uji Kruskal-Wallis Ekstrak Buah Pare padaMortalitas Larva Aedes aegypti

\begin{tabular}{lc}
\hline Uji Kruskal-Wallis & $\begin{array}{l}\text { Ekstrak Buah Pare pada } \\
\text { Mortalitas Larva }\end{array}$ \\
\hline Signifikansi & 0,005 \\
\hline
\end{tabular}

Hasil uji Kruskal-Wallis menunjukkan bahwa terdapat perbedaan bermakna $(p=0,005)$ antara kelompok konsentrasi ekstrak buah pare pada mortalitas larva Aedes aegypti. Adanya suatu perbedaan bermakna karena ekstrak buah pare mengandung metabolit sekunder, seperti flavonoid, alkaloid, saponin, dan steroid yang memiliki efek sebagai larvasida.

Flavonoid bekerja sebagai inhibitor kuat sistem pernapasan atau sebagai racun pernapasan. Flavonoid mempunyai cara kerja, yaitu dengan masuk ke dalam tubuh larva melalui sistem pernapasan yang kemudian akan menimbulkan gangguan pada saraf serta kerusakan pada sistem pernapasan dan mengakibatkan larva tidak bisa bernapas dan akhirnya mati (Cania \& Setyaningrum 2013). Penelitian Pueyo \& Calvo(2011) menyatakan bahwa flavonoid memiliki efek sebagai inhibitor asetilkolinesterase.

Chaieb(2010) menyatakan bahwa saponin memiliki efek mengganggu pola makan sehingga nafsu makan larva menjadi menurun dan larva mati kelaparan.Selain itu, efek yang ditimbulkan oleh saponin adalah mengganggu pertumbuhan larva yang ditandai dengan pertumbuhan pada stadium larva menjadi memanjang serta kegagalan dalam pertumbuhan serta perkembangan menuju stadium lebih lanjut. Saponin dapat menurunkan aktivitas enzim pencernaan dan penyerapan makanan. Pengaruh saponin terlihat pada gangguan fisik serangga, yaitu merusak lapisan lilin yang melindungi tubuh serangga bagian luar sehingga kehilangan banyak cairan tubuh dan mengakibatkan kematian. Selain merusak lapisan lilin, saponin juga masuk ke sistem pernapasan dan mengganggu proses pernapasan serangga serta merusak mukosa saluran pencernaan larva 
sehingga dinding traktus digestivus mengalami korosif (Haditomo, 2010; Irwan et al, 2007).

Penelitian Rijn et al(2010) menyatakan bahwa alkaloid memiliki efek inhibitor asetilkolinesterase sehingga menghambat kerja sistem saraf. Alkaloid dapat mendegradasi membran sel untuk masuk ke dalam tubuhmelalui kulit maupun jalur pencernaan dan merusak sel.Selainitu, alkaloid dapat mengganggu sistem kerja saraf larva dengan menghambat kerja enzim asetilkolinesterase sehingga terjadi penumpukan asetilkolin. Senyawa alkaloid menyebabkan warna tubuh larva menjadi transparan dan gerakan tubuh larva melambat bila dirangsang sentuhan. Selain itu, alkaloid dapat menyebabkan kerusakan pada regio thoraks dan abdomen pada larva yang ditandai dengan kerusakan epitel dan neuropil pada midgut(Cania \& Setyaningrum, 2013; Satria \& Prasetyowati, 2012; Perumalsamy et al, 2013).

Penelitian Perumalsamy et al(2015) menyatakan bahwasenyawa steroid dapat mengganggu struktur octopamine, suatu struktur pada otak yang menempatkan serangga dalam keadaan waspada dan mengatur aktivitas motorik larva. Jika terjadi gangguan di struktur octapamine maka terjadi gangguan aktivitas larva sehingga meningkatkan mortalitas larva.Penelitian Brooker et al(2011) menyatakan bahwa jika terjadi gagguan struktur octapamine maka efek yang timbul adalah gangguan neuromuscular dan bahkan kematian larva. Berdasarkan penelitian Gosh(2013) steroid juga menghambat sterol carrier protein (SCP) sehingga larva tidak dapat mengubah sterol menjadi kolesterol sehingga akan mengganggu proses pertumbuhan dan perkembangan larva.

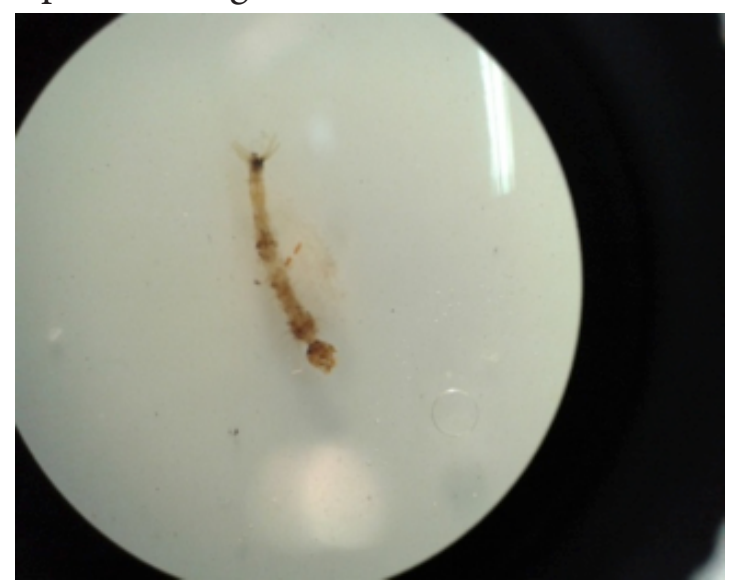

Gambar 1 Larva Aedes aegypti Telah Mati

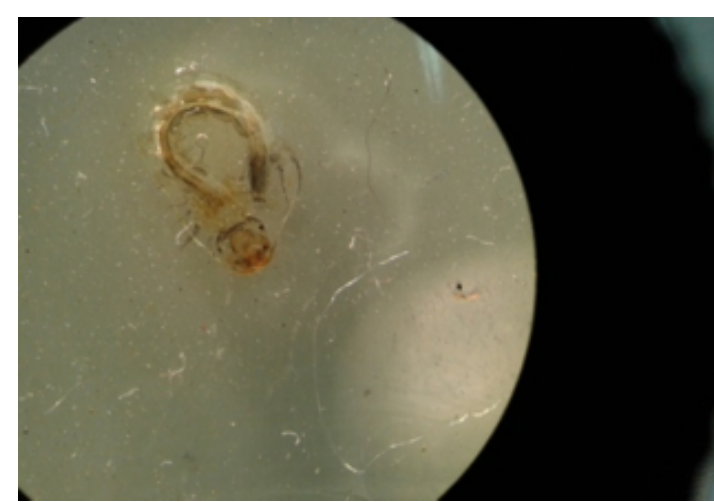

Gambar 2 Larva Aedes aegypti Masih Hidup

Tabel 4Hasil Uji Mann-Whitney Ekstrak Buah Pare pada Mortalitas Larva Aedes aegypti

\begin{tabular}{ccc}
\hline $\begin{array}{c}\text { Kelompok } \\
\text { Konsentrasi }\end{array}$ & & Signifikansi \\
\hline \multirow{2}{*}{ Kontrol } & $0,8 \%$ & 0,005 \\
negatif & $1,6 \%$ & 0,005 \\
& $3,2 \%$ & 0,005 \\
& $6,4 \%$ & 0,003 \\
$0,8 \%$ & $1,6 \%$ & 0,007 \\
& $3,2 \%$ & 0,008 \\
& $6,4 \%$ & 0,005 \\
$1,6 \%$ & $3,2 \%$ & 0,008 \\
& $6,4 \%$ & 0,005 \\
$3,2 \%$ & $6,4 \%$ & 0,018 \\
\hline
\end{tabular}

Berdasarkan hasil uji Mann-Whitney didapatkan perbedaan bermakna antara setiap konsentrasiekstrakbuah pare dan setiap konsentrasi ekstrakbuah pare dan kontrol negatif. Kematian larva Aedes aegypti mulai terjadi pada konsentrasi $0,8 \%$ dengan rerata kematian 8,3 , sementara rerata kematian tertinggi terdapat pada konsentrasi $6,4 \%$ dengan nilai 20.Dengandemikiandapat disimpulkan bahwa kematian larva Aedes aegypti berbanding lurus dengan peningkatan konsentrasiekstrakbuah pare.

Menurut Wijaya(2009), kenaikan suatu konsentrasi ekstrak juga diikuti dengankenaikan jumlah kematian larva. Menurut Istianah et al(2013), peningkatan kosentrasi menunjukkan peningkatan kandungan bahan aktif yang terkandung dalam larutan uji yang semakin 
besar sehingga akan semakin kuat dalam mengganggu kerja fisiologis larva danakhirnya jumlah mortalitas larva akan semakin meningkat dikarenakan bahan aktif yang masuk kedalam tubuh larva semakin banyak. Teori tersebut sesuai dengan penelitian Tyas et al(2014)yang menyatakan bahwa presentase rata-rata mortalitas larva meningkat seiring denganpeningkatan konsentrasi ekstrak, rebusan, dan rendaman daun papaya. Berdasarkan penelitian Rahmawati et al(2013) semakin tinggi konsentrasi ekstrak biji mimba (Azadirachta indica) maka mortalitas larva Culex sp juga semakin meningkat

Tabel 4 Hasil Analisis Probit Ekstrak Buah Pare pada Mortalitas Larva Aedes aegypti

\begin{tabular}{lll}
\hline Spesies & $\mathbf{L C}_{50}$ & $\mathbf{L C}_{30}$ \\
\hline Aedes & $1,207 \%$ & $2,759 \%$ \\
aegypti & $(1,044 \%-$ & $(2,445 \%-$ \\
& $1,351 \%)$ & $3,227 \%)$ \\
\hline
\end{tabular}

Pada penelitian ini dilakukan uji analisis probit dan didapatkan nilaiLC50 sebesar 1,207\% dengan interval $1,044 \%-1,351 \%$ yang menandakan bahwauntuk membunuh 50\% populasi larva Aedes aegypti pada satu kontainer penelitian yang berjumlah 20 larva dibutuhkan konsentrasi $1,207 \%$ dengan batas tertinggi $1,044 \%$ dan batas terendah $1,351 \%$. Sementara itu, nilai LC90,yaitu untuk membunuh 90\% populasi larva Aedes aegypti pada satu kontainer yang berjumlah 20 larva dapat menggunakan konsentrasi 2,759\% dengan interval $2,445 \%-3,227 \%$.

Pada penelitian Singh et al(2006) dengan menggunakan ekstrak buah pare pada larva Aedes aegypti didapatkan nilai LC50 $1.45 \%$ dengan interval $1,27 \%-1,69 \%$ dan nilai LC90 sebesar4,46\%. Menurut Patil et al(2014) terdapatnya perbedaan tingkat toksisitas pada setiap ekstrak bergantung pada kandungan insektisida setiap ekstrak, tingkat kelarutan pada berbagai macam pelarut yang sangat bervariasi pada setiap tanaman, bagian tanaman, usia bagian tanaman yang akan diekstrak, pelarut untuk ekstraksi, variasi musim, dan spesies serangga yang dijadikan target. Menurut Kweka et al(2011) perbedaan kandungan metabolit sekunder bergantung pada variasi genetikdan keadaan geografis atau bisajugadipengaruhiolehfaktor abiotik, seperti angin, kelembapan, serta metode ekstraksi.

\section{KESIMPULAN}

a. Pada konsentrasi terkecil, yaitu 0,8\%, ekstrak buah pare sudah memberikanefek mortalitas padalarva Aedes aegypti.

b. Semakin tinggi konsentrasi ekstrakbuah pare maka mortalitas larva Aedes aegypti yang terjadi semakin meningkat.

c. Nilai LC50 ialah $1,207 \%$ dengan interval $1,044 \%$ - 1,351\% dan nilai LC90adalah $2,759 \%$ dengan interval $2,445 \%-3,227 \%$.

\section{DAFTAR PUSTAKA}

Bisset, J.A., Rodriguez, M.M., Ricardo, Y., Ranson, H., Perez, O., Vazquez, A., (2011). Temephos resistance and esterase activity in the mosquito Aedes aegypti in Havana, Cuba increased dramatically between 2006 and 2008. Medical and Veterinary Entomology. 25, pp. 233-239.

Britto, JD, Gracelin, HS 2011, 'Phytochemical Analysis and Antibacterial Activity of Momordica charantia Desscourt, A Known Medicinal Plant', Journal of Basic and Applied Biology, vol.5, no.1, pp. 307-311.

Brooker, AJ, Maldonado, MIG, Irving, S, Bron, JE, Longshaw, M, Shinn, AP 2011, 'The effect of octopaminergic compounds on the behaviour and transmission of Gyrodactylus', BioMed Central, vol.4, no.207, pp. 1-10.

Budrat, P, Shotipruk, A 2008, 'Extraction of Phenolic Compounds from Fruits of Bitter Melon (Momordica charantia) with Subcritical Water Extraction and Antioxidant Activities of These Extracts', Chiang Mai J. Sc, vol.35, no.1, pp. 123130.

Cahyadi, R 2009, Uji Toksisitas Akut Ekstrak Etanol Buah (Momordica charantia L.) Terhadap Larva Artemia salina Leach Dengan Metode Brine Shrimp Lethality Test (BST), Skripsi, Universitas Diponegoro. 
Cania, E, Setyaningrum, E 2013, 'Uji Efektivitas Larvasida Ekstrak Daun Legundi (Vitex trifolia) Terhadap Larva Aedes aegypti', Medical Journal of Lampung University, vol.2, no.4, hlm. 52-60.

Chaieb, I 2010, 'Saponin as Insecticides: a Review' Tunisian Journal of PlantProtection, vol.5, pp. 39-50.

Depertemen Kesehatan Republik Indonesia (Depkes RI) 2007, Kebijakan Obat Tradisional Nasional.

Ghosh, A 2013, 'Efficacy of phytosterol as mosquito larvicide', Asian Pacific Journal of Tropical Disease, vol.3, no.3, pp.252.

Gupta, M, Sharma, Sushil, Gautam, AK, Bhadauria, R 2011, 'Momordica charantia, Linn Nature's Silent Healer (Karela)', International Journal of Pharmaceutical Sciences Review and Research, vol.11, no.1, pp. 32-37.

Haditomo, I 2010, Efek Larvasida Ekstrak Daun Cengkeh (Syzygium aromaticum L.) Terhadap Aedes aegypti L. Skripsi. Universitas Sebelas Maret Surakarta.

Harfriani, H 2012, 'Efekstivitas Larvasida Ekstrak Daun Sirsak dalam Membunuh Jentik Nyamuk', Jurnal Kesehatan Masyarakat, vol.7, no,2, hlm. 164-169.

Hasna, Husni, Purnama, NN 2013, 'Keefektifan Ekstrak Daun Pare dalam (Momordica charantia) dalam Mengendalikan Crocidokomia pavonanaF. Pada Tanaman Sawi' ,J. Floratek, vol.8, hlm. 52-63.

Istianah, MA, Utami, WS, Ameliana, L 2013, 'Efektivitas Biolarvasida Minyak Daun Jeruk Purut (Citrus hystrix) Terhadap Larva Instar III Nyamuk Aedes aegypti', Artikel Ilmiah Hasil Penelitian Mahasiswa. hlm. 1-4.

Irwan, A, Komari, N, Rusidana 2007, 'Uji Aktivitas Ekstrak Saponin Fraksni n-Butanol dari Kulit Batang Kemiri (Aleurites moluccana Wild) Pada Larva Nyamuk Aedes aegypti', Sains dan Terapan Kimia, vol.1, no.2, hlm. 93-101.

Kweka, EJ, Mramba, N, Mosha, F, Silva, AG 2011, 'Insecticidal activity of the essential oil from fruits and seeds of Schinus terebinthifolia Raddi against African malaria vectors', Parasite \& Vectors, vol.4, no.129, pp.1-10.

Ludvik, GF 2007, Insecticide, in: Encyclopedia of Science \& Technology 10th. McGraw-Hill, New York, pp. 252-256.

Majidah, A, Dini, V, Fitriany, RN, Wulandari, RA 2010, 'Faktor Iklim dan Angka Insiden Demam Berdarah Dengue di Kabupaten Serang', Makara Kesehatan, vol.14, no.1, hlm. 31-38.

Minarni, E, Armansyah, T, Hanafiah, A 2013, 'Daya Larvasida Ekstrak Etil Asetat Daun Kemuning (Murraya paniculata (L) Jack) Terhadap Larva Nyamuk Aedes aegypti', Jurnal Medical Veterinaria, vol.7, no.1, hlm. 27-29.

Natadisastra, D, Agoes, R 2009, PARASITOLOGI KEDOKTERAN Ditinjau dari Organ Tubuh yang Diserang, EGC, Jakarta.

Nisa, K, Hargono, A, Ridha, MR 2012, 'Aedes aegypti in Sekumpul Village (Martapura - District of Banjar, South Kalimantan) is tolerant to Temephos', Epidemiology and Zoonosis Journal, vol.4, no.2, hlm. 66-72.

Nusmara,KG 2012, Uji Stabilitas Fisik dan Aktivitas Pertumbuhan Rambut Tikus Putih dari Sediaan Hair Tonic yang Mengandung Ekstrak Etanol Daun Pare (Momordica charantia), Skripsi, Universitas Indonesia.

Patil, CD, Borase, HP, Salunkhe, RB, Suryawanshi, RK, Narkhade, CP, Salunke, BK, Patil, SV 2014, 'Mosquito Larvicidal Potential of Gossypium hisutum (Bt Cotton) Leaves Extract Against Aedes aegypti and Anopheles stephensi larvae, J Arthropod-Borne Dis, vol.8, no.1, pp.91-101.

Perumalsamy, H, Jang, MJ, Kim, JR., Kadarkarai, M, Ahn, YJ 2015, 'Larvicidal activity and possible mode of action of four flavonoids and two fatty acids identified in Millettia pinnata seed toward three mosquito species', BioMed Central, vol.8, no.237, pp. 1-14.

Perumalsamy, H, Kim, JR, Oh, S.M, Jung, JW, Ahn, YJ, Hyung, WK 2013, 'Novel Histopathological and Molecular Effects of Natural Com- 
pound Pellitorine on Larval Midgut Epithelium and Anal Gills of Aedes aegypti, PLOS ONE, vol.9, no.11, pp.1-9.

Pueyo, IU, Calvo, MI 2011, 'Flavonoid as Acetylcholinesterase Inhibitors. Current Medical Chemistry, vol.18, pp. 5289-5302.

Rahmawati, E., Hidayat, MT, Budijastuti, W 2013, 'Pemanfaatan Biji Mimba (Azadirachta indica) Sebagai Larvasida Nyamuk Culex sp', LenteraBio, vol.2, no.3, pp. 207-210.

Remia, KM, Logaswamy, S 2010, Larvicidal efficacy of leaf extract of two botanicals againts the mosquito vector Aedes aegypti (Diptera: Culicidae), Indian J Nat Prod Resour, vol.1, no.2, pp. 208-212.

Sapir, DG, Schimmer, B 2005, 'Dengue fever: new paradigms for a changing epidemiology', Emerging Themes in Epidemiology, vol.2, no.1, pp. 1-10.

Satria, W, Prasetyowati, H 2012, 'Daya Larvasida Ekstrak Biji Srikaya (Annona Squamosa) dengan Rentang Waktu Penyimpanan yang Berbeda Terhadap Larva Culex quinquefasciatus', Aspirator, vol.4, no.1, pp. 21-26.

Saryono, Syafruddin, D, Sumanto, D 2012, Distribusi Resistensi Nyamuk Aedes aegypti terhadap Insektisida Sipermetrin di Semarang, Seminar Hasil-Hasil Penelitian LPPM UNIMUS. pp 263-269.

Singh, RK, Dhiman, RC, Mittal, PK 2006, 'Mosquito larvicidal properties of Momordica charantia Linn (Family: Cucurbitaceae)', J Vect Borne Dis., vol.43, pp. 88-91.

Tyas, DW, Wahyuni, D, Hariyadi, S 2014, 'Perbedaan Toksisitas Esktrak, Rebusan dan Rendaman Daun Pepaya (Carica papaya, L) Terhadap Mortalitas Larva Nyamuk Aedes aegypti', Pancara, vol.3, no.1, pp.59-68.

Wijaya, LA 2009, 'Daya Bunuh Ekstrak Biji Kecubung (Datura metel) Terhadap Larva Aedes aegypti, Skripsi, Universitas Sebelas Maret Surakarta.
World Health Organization (WHO) 2011, Comprehensive Guidelines for Prevention and Control of Dengue and Dengue Haemorrhagic Fever. 